\title{
The story of the Berkeley library theft
}

\author{
By Peter E. Hanff \\ Coordinator of Technical Services \\ The Bancroft Library \\ University of California, Berkeley
}

\section{How one library successfully apprehended a book thief, with some recommendations for collection security.}

$\mathbf{T}$ he library and bookselling communities have been aware for some time that book theft is on the rise and that large-scale theft is seriously damaging research collections. In response to the problem, the Rare Books and Manuscripts Section of ACRL, the Antiquarian Booksellers Association of America, and the Society of American Archivists have all issued publications concerned with theft. However, despite the general information available, most libraries are still not prepared to act effectively if a theft occurs. This report details a case that occurred last summer on the Berkeley campus of the University of California. The events and actions taken in the case may serve as a guide for other libraries in future thefts.

The reader should bear in mind that Berkeley had already made plans for dealing with theft. The General Library had appointed a Library Security Council, and The Bancroft Library, Berkeley's rare book and manuscript library, had appointed me as its Security Officer some years ago. In addition we had discussed library theft with the University of California Police Department and had initiated discussion with the District Attorney in Berkeley about the importance of prosecuting book thieves. My awareness was also heightened because I was chairing the Rare Books and Manuscripts Section's Security Committee and was serving on the planning committee for the Oberlin Conference on Theft. ${ }^{1}$

Ironically, just two weeks after I completed a paper on protocols for dealing with library theft, The Bancroft Library received a letter from the antiquarian bookseller, Warren R. Howell, asking if we would check half a dozen titles against our catalog. Our acquisitions staff quickly determined that Bancroft held none of the titles, but that the titles were owned by the UC Berkeley General Library; the General Library copies proved not to be on the shelves nor charged out. We gave this information to Howell, who brought the books to me the next day for inspection. He explained that although he and his staff could find no visible marks of current ownership on the books, several encounters with the young man who offered them for sale had left Howell suspicious. The young man had given a Berkeley address and telephone number, and Howell had wondered if, by chance, the books had come from a Berkeley library.

Our close inspection of the volumes revealed almost immediately that spine call number labels and other marks of ownership normally placed in books by the General Library had been skillfully removed or covered over by old book stickers or old bookplates. Only the experience of working regularly with the marking patterns of General Library books made it evident that the books had been tam-

${ }^{1}$ The Oberlin Conference on Theft, funded by a grant from the H.W. Wilson Foundation, was held at Oberlin College, Ohio, September 12-13, 1983 (see CむRL News, October 1983, pp. 362-63. 
pered with-individuals less familiar with our practices would not have discerned the tampering.

I alerted the University Police and the assistant university librarian responsible for the General Library collections and arranged a meeting between them and Warren Howell for Wednesday of the following week. We intended to evaluate the evidence and determine what action to take.

Over the weekend I described the recovery of the books to one of the General Library security officers and to one of Berkeley's antiquarian booksellers. On Sunday that bookseller spotted some familiar volumes, also with their marks of ownership apparently removed, in another bookshop. He obtained permission to bring the books to me. On Monday morning the books were checked against the General Library catalog, and once again we determined that these were books that belonged to the University of California at Berkeley. The Berkeley bookseller alerted booksellers around the Bay Area, several of whom recognized the description of the young man and the types of books he had been offering for sale. At least six booksellers had purchased books from him. In most instances the young man gave the same name, but the addresses and telephone numbers varied. In the Berkeley shop where books had been recovered he had used a different surname, so we could not be sure we were dealing with only one individual. I alerted the University Police to this new information, and they asked me to accompany them to the bookstore to identify additional volumes left on approval. My inspection revealed that these books, too, had their marks of ownership carefully removed and bore stickers identical to those in books returned by Howell.

On the basis of my identification of these as General Library books, the University Police were able to apprehend the young man as he collected payment from the bookseller. Later in the afternoon, the suspect was arrested and brought back to the campus for booking and interrogation. At first he refused to identify himself, but when pressed gave the name he had used with Warren Howell. He was remanded to the county jail on $\$ 15,000$ bail.

The meeting scheduled for Wednesday had now taken on a different character. Several booksellers who had purchased books from the suspect brought those books with them to the meeting. One by one, three of the booksellers were taken into an adjacent room and shown a photographic line-up of various individuals. Each made a positive identification of the suspect. Because the suspect had told Warren Howell repeatedly that he had additional books for sale at home, the police now felt they had sufficient evidence to secure a search warrant. That afternoon the warrant was issued and I accompanied the police to the suspect's rented rooms in a Berkeley house. There we recovered about 250 volumes, most in good leather bindings, many of them French imprints of the 18th century. In addition, we recovered an array of equipment and supplies for repairing and dyeing leather, eradicating ink, and dissolving adhesives, as well as old bookplates and facsimile bookplates (including a supply of fresh book stickers identical to those found in many of the books recovered from the booksellers, together with paper stain apparently used to "age" the stickers.)

The evidence was gathered and brought back to

\section{Spine call number labels had been skillfully removed.}

the campus for inventory. Volunteers from the Reference Department of the General Library carried out the inventory, which took a number of days. In the meantime, I consulted frequently with legal counsel on campus. I stressed that the Library was anxious to prosecute the case to the full extent of the law and that we wished to be sure the matter was handled effectively. In criminal cases affecting University property, the University Police are responsible for preparing the evidence for the District Attorney; University Counsel is not directly involved.

On advice from counsel, I had already sent a memorandum to the Chief of the University Police stressing the importance of keeping the District Attorney fully informed of the development of the case. Although the arresting officers told the District Attorney that we had been issued a search warrant, they did not immediately transmit information that a large number of books had been recovered. This was largely because they wanted to complete the inventory of the evidence and have the material appraised so that they could give the District Attorney a full accounting of the value of the recovered books. As a result of the delay, the suspect was able to plead guilty to a misdemeanor charge (the original charge at the time of his arrest), although in fact the value of the recovered books was sufficient to justify a felony grand theft charge.

Warren Howell volunteered to make the appraisal of the books and established their value at $\$ 25,000$. This information was conveyed to the District Attorney who, after consultation with me, filed an additional felony-level charge against the suspect. Privately I was told that the defense attorney would undoubtedly be able to have the larger charge dismissed, because he would be able to show that the recovery on the search warrant was part of the same case as the original arrest. Nevertheless, it was important to the Library that the more serious charge be filed so that we could ensure the most thorough possible pursuit of the case. 
It is important to point out that the District Attorney's office has been seriously affected by the passage of Proposition 13 by California voters. The heavily occupied staff must set strict priorities in handling prosecutions. Because Berkeley is a large, urban campus, its Police Department also contends with a sizable case load. As an example, I noticed that as we were developing the book-theft case,

\section{The bookselling community}

\section{plays a vital role in theft}

\section{cases.}

$\$ 60,000$ worth of oriental rugs were stolen from the University President's house - that places the value of the Library's loss in some perspective.

Reaching the District Attorney by telephone to discuss the case was frustrating and timeconsuming. Nevertheless, with persistence, I was able to have several valuable discussions with him about our belief that the case needed to be pursued vigorously. Several possible bargaining positions were proposed by the defense, but the Library chose to prosecute, even though we understood that the likely outcome was to be no more than compensation for damage to the books and staff time required for inventorying and re-accessioning the recovered books.

The District Attorney took into account the Library's interest in determining how the thefts were carried out, and he arranged with the defense attorney that the suspect be brought to the Library for questioning by the staff. The interview, which involved eight staff members, took approximately an hour and a half and provided valuable insight into the attitudes of the suspect and the methods he used in carrying out the thefts. Ultimately, as had been anticipated, the suspect was permitted to plead guilty to the second charge after it was revised to a misdemeanor charge. He was ordered to pay restitution to the Library and to the booksellers who had purchased books from him. His case is now under the jurisdiction of a County Probation Officer.

Among the lessons learned by the Library in pursuing the case, some are likely to have general application:

1. Once a case is discovered, it is essential that one staff member be assigned to follow through with the case.

2. The bookselling community plays a vital role in identifying and resolving cases of book theft. The booksellers in the Bay Area, through their own communication network, recognized the descrip- tion of the suspect and telephoned the Library at once to identify books they had purchased; they returned the books immediately and cooperated in identifying the suspect and establishing the value of the books that had been stolen.

3. The Library subscribes to Bookline Alert: Missing Books and Manuscripts (BAMBAM), the national online computer record. When informed of the nature of the theft, BAMBAM circulated a report to make other subscribers aware of the theft from Berkeley.

4. Following recommendations of the Antiquarian Booksellers Association of America and the Rare Books and Manuscripts Section, we alerted the FBI office in San Francisco of the case. Normally the FBI can be involved in such cases only when the value of the theft is greater than $\$ 5,000$, which was certainly the situation here. However, there was no evidence that the case extended beyond the local area and we were satisfied that the case could be handled locally.

5. Before we had a chance to prepare a public statement, several newspaper reporters telephoned for additional information about the case as reported on the court blotter. If we experience another theft, we will prepare a public statement immediately.

6. We kept in close touch with the University Police, and in particular with the two officers who had arrested the suspect; when it became apparent that there had been a temporary break in communication between the District Attorney and the Police, we arranged a special meeting with the Campus Chief of Police. He agreed to have the case well documented so that information could be presented to the other University Police Departments throughout the nine-campus system of the University of California. He kept the other Departments posted as the case developed.

7. We kept track of the amount of staff time spent on the case, including my time, the time of the volunteers who prepared the inventory, the time spent in interviewing the suspect, together with estimates of the cost to repair the books and to return them to the collection; these expenses became the basis for our claim for restitution.

8 . We interviewed the suspect to learn as much as possible about how he gained access to the book stacks, how he removed the books from the General Library, his plan of operation, and the names of booksellers he had approached. Wherever I had independent knowledge of his activities, I was able to corroborate his account; I therefore presumed that his other statements were also essentially truthful.

9. We made considerable effort to keep the staff immediately involved in the case informed by direct discussion and by publishing statements in the General Library's weekly newsletter. We also granted interviews to the media. Nevertheless, even greater effort to keep the staff informed of developments in a case of theft is essential because 
such cases have a strong impact on staff morale. A particularly difficult aspect of this case was the impact on the staff when it became clear that the suspect had initially been allowed to plead guilty to a misdemeanor; filing the second, felony charge was valuable not only because of the size of the theft but also because it reflected the harm done to the library.

10. To follow the case as it progressed through the court required considerable persistence because the courts, the District Attorney, and the University Police are not well equipped to direct information back to the Library. Our concerned Berkeley bookseller also pursued the case by attending the court hearings; he secured a copy of the court transcript and presented it to us for our files.

\section{Conclusions}

There is always room for improvement in security planning. On the basis of our experience in this case, we have a better understanding of weaknesses in our present security arrangements and are taking steps to correct them. The General Library at Berkeley is a large, complex organization housed in numerous buildings on campus. The thefts occured in the controlled-access book stacks of the Main Library Building (built in 1911), an area posing difficult problems because of its age and design. The theft, which involved mostly 18 th-century materials, prompted us to adopt a policy already under consideration: the 18th-century imprints have been designated en bloc to be transferred to the custody of The Bancroft Library for greater safekeeping. The announcement of the transfer has been well received by the campus community, in part because of the wide publicity of the theft case. We were able to take advantage of this major incident to bring about sound changes in policies and prac- tices and to overcome the inertia characteristic of large institutions.

Advance planning is exceedingly important. Designation of a staff security officer is vital, and the security officer needs sufficient authority to make quick decisions in dealing with theft. The Bancroft Security Officer is a library administrator, as are the three members of the General Library Security Council. All had opportunity to discuss security concerns before the incident. All had reviewed the guidelines promulgated by the ACRL Rare Books and Manuscripts Section, and had had occasion to be in fairly close communication with the University Police.

Demands on staff time in such cases are considerable-I wrote frequent reports on the progress of the case and talked often with General Library administration about possible strategies in dealing with the matter. I needed to be in touch with the Police and District Attorney far more often than I anticipated. A significant factor during the development of the case was staff concern and morale; a theft of such size was viewed by many as a violation of the Library's integrity, and the staff was eager for the case to be solved. We hope there will be no future incidents of theft from the Library, but we are now better equipped to respond to such incidents if they occur.

On Monday, November 14, 1983, Michael Kunashko pled guilty in the case of State of California v. Michael Kunashko. He had earlier pled guilty to misdemeanor grand theft in a related action. He received a six month sentence to county jail, suspended, and was placed on probation and ordered to pay restitution to the University of California and to booksellers to whom he had sold stolen books.

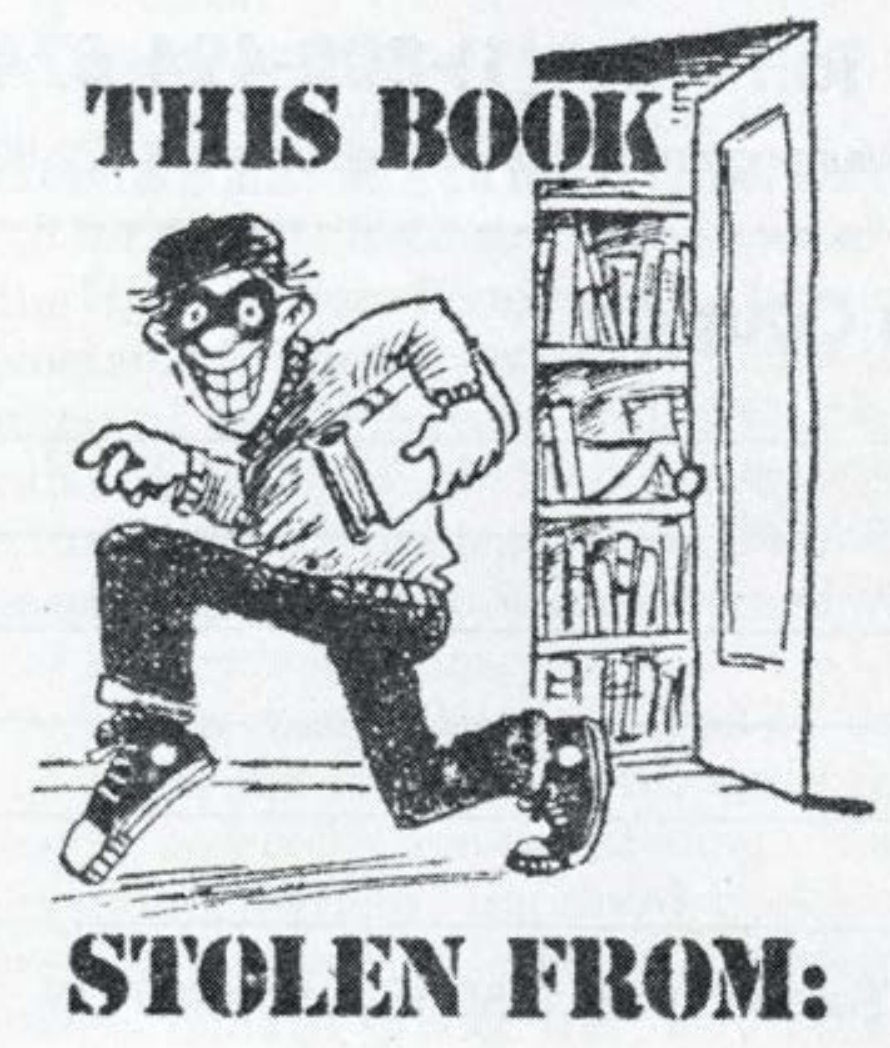

Rubber stamp art enthusiasts can now mark their holdings with the stamp shown here from Funny Business.

It sells for $\$ 5.75$ and may be ordered from Funny Business, 2129 Second Avenue, Seattle, WA 98121; (206) 623-7842.

Add $\$ 1.00$ for shipping.

( 1981 , Funny Business 


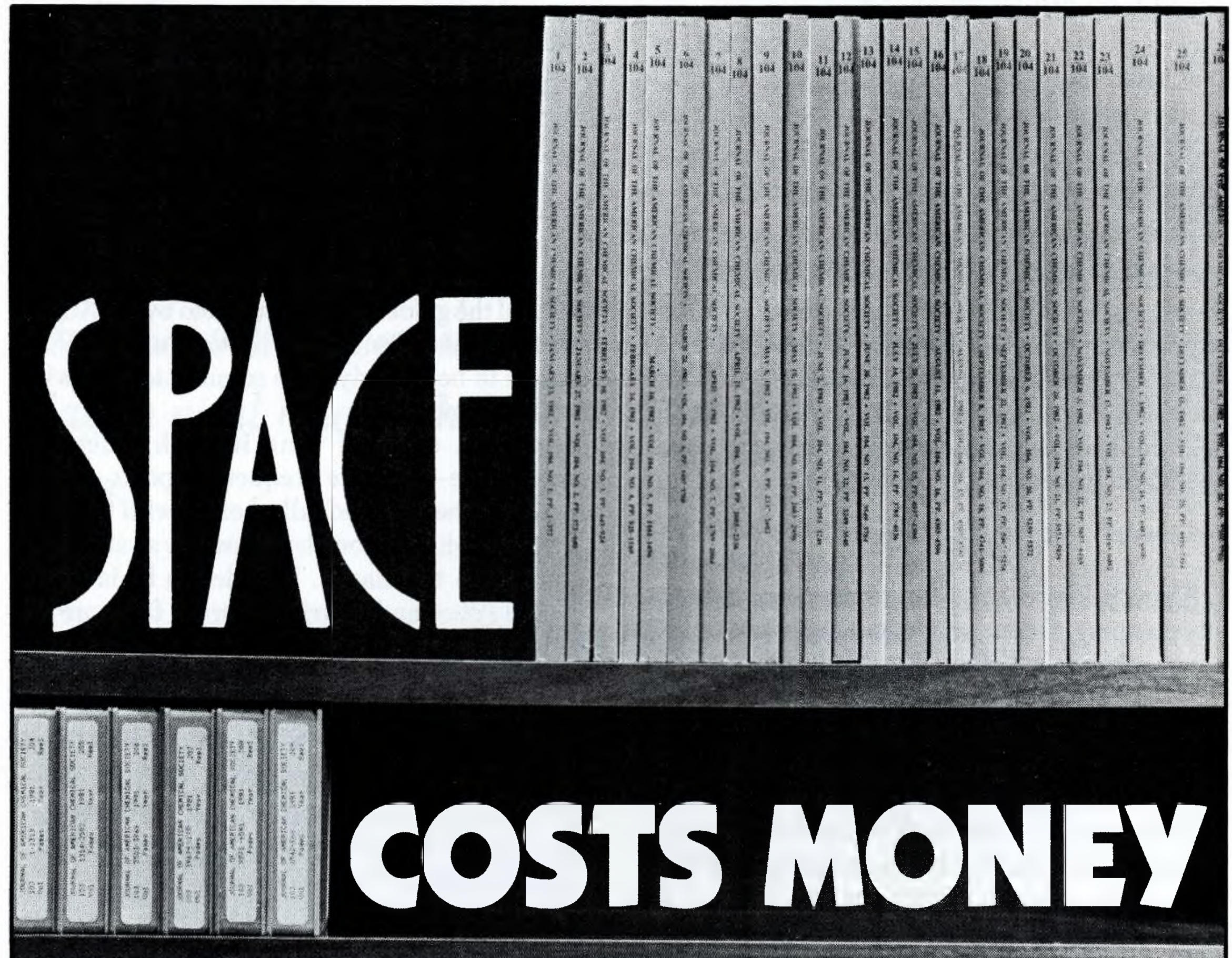

When you manage a library these days, you're well aware that space is precious. And additional shelves for backfile volumes are expensive.

Well, the American Chemical Society knows your concerns. That's why all the Society's 20 primary publications in the field of chemistry are available in microfilm editions - including complete volumes back to 1879.

\section{Start Saving Space In Your Chemical Reference Files Now!}

If you are setting up a microfilm system, expanding or changing one, or just want to discuss the possibilities-an ACS Sales Representative is ready to work with you. Just fill in the coupon below, or better yet, call us:

\section{American Chemical Society}

Our 16th Year in Micropublishing
Toll Free (1)-800-424-6747

Washington, D.C. area residents call 872-8065

\section{ACS Microfilm Editions-Information Coupon}

Yes, please send me more Name

information on American

Chemical Society publications

as indicated below:

$\square$ ACS Microforms Catalog

$\square$ ACS Books \& Journals Catalog (includes microforms information)

Organization

Address

City, State, Zip

Country

Telephone

Return this coupon to: American Chemical Society, Sales Office, 1155 16th Street, N.W., Washington, D.C. 20036 